\title{
STUDY ON C-REACTIVE PROTEIN IN CASES OF PRE-ECLAMPSIA
}

\author{
Chitra Sinha1, Ram Binay Sinha², Chander Kiran ${ }^{3}$
}

${ }^{1}$ Associate Professor, Department of Obstetrics and Gynaecology, Patna Medical College and Hospital, Patna, Bihar.

2 Professor, Department of Biochemistry, Patna Medical College and Hospital, Patna, Bihar.

3Professor and HOD, Department of Obstetrics and Gynaecology, Patna Medical College and Hospital, Patna, Bihar.

\section{ABSTRACT}

\section{BACKGROUND}

Pre-eclampsia is one of the most frequent obstetric complication occurring in about $5 \%$ to $10 \%$ of pregnancies. It is one of the leading causes of maternal and perinatal morbidity and mortality. C-reactive protein is a marker of tissue damage and inflammation and was proposed to play a role in eliciting the inflammatory response characteristic of pre-eclampsia.

The objective of this study is- C-reactive protein, a sensitive marker of tissue damage and inflammation was proposed to play a role in eliciting the inflammatory response characteristic of preeclampsia. The present study is directed towards determining the association of serum C-reactive protein and preeclampsia.

The aim of this study is this study on C-reactive protein in preeclampsia will serve as standard guideline for this part of the country.

\section{MATERIALS AND METHODS}

The study has been conducted in the Dept. of Obstetrics and Gynaecology, Patna Medical College and Hospital, Patna. Serum estimation of C-reactive protein was done in Dept. of Biochemistry in diagnosed cases of pre-eclampsia by turbidimetric method; 150 women of pre-eclampsia were selected as study group and 50 normotensive pregnant women were selected as control group. All women were in the age group of 20 - 35 yrs. and were in $3^{\text {rd }}$ trimester of pregnancy.

Statistical Analysis- Descriptive data were presented as mean \pm SD and range values. Comparison between the control group and study group was done by Chi-square test. For all the tests, the probability value (p-value) of less than 0.05 was considered statistically significant.

Study Design- Observational study.

\section{RESULTS}

The incidence of pre-eclampsia is higher in primi gravida and women of low socioeconomic status. The mean systolic blood pressure was of $117.88 \mathrm{~mm}$ of mercury in control group and $163.37 \mathrm{~mm}$ of mercury in study group. The mean diastolic blood pressure in control group was $74.44 \mathrm{~mm}$ of mercury and $108.50 \mathrm{~mm}$ of mercury in study group. Range of C-reactive protein was quite high in cases of the study group $(30.12-90 \mathrm{mg} / \mathrm{L})$ than the control group $(2.2-16.15 \mathrm{mg} / \mathrm{L})$.

\section{CONCLUSION}

Among various markers of inflammation in pre-eclampsia, C-reactive protein is strongly associated with inflammatory process and is a sensitive index of overall inflammatory activity in the body as CRP is markedly elevated in cases of pre-eclampsia.

\section{KEYWORDS}

Preeclampsia, Inflammatory Response and C-Reactive Protein.

HOW TO CITE THIS ARTICLE: Sinha C, Sinha RB, Kiran C. Study on c-reactive protein in cases of pre-eclampsia. J. Evolution Med. Dent. Sci. 2017;6(68):4887-4889, DOI: 10.14260/Jemds/2017/1059

\section{BACKGROUND \\ Pre-eclampsia is one of the most frequent obstetric complication occurring in about $5 \%$ to $10 \%$ of pregnancies. It is one of the leading causes of maternal and perinatal morbidity and mortality. According to WHO, systemic review hypertensive disorder contributes to $16 \%$ of maternal mortality.}

Financial or Other, Competing Interest: None.

Submission 04-07-2017, Peer Review 13-08-2017,

Acceptance 19-08-2017, Published 24-08-2017.

Corresponding Author:

Dr. Chitra Sinha,

P-12 Vidyapuri,

Doctor's Colony Kankarbagh,

Patna-800020

Bihar.

E-mail: chitra.sinha@gmail.com

DOI: $10.14260 /$ jemds $/ 2017 / 1059$

\section{(c) $(1)$}

ACOG, task force on hypertension in pregnancy in its report (2013) described preeclampsia as an evolving, dynamic and multisystemic process. Hypertensive disorder of pregnancy represents a group of conditions and is classified as gestational hypertension preeclampsia, chronic hypertension and preeclampsia superimposed on chronic hypertension.

Pre-eclampsia is characterised by systolic blood pressure equal to or more than $140 \mathrm{mmHg}$ and diastolic blood pressure equal to or more than $90 \mathrm{mmHg}$ with proteinuria ( $\geq 300 \mathrm{mg} / 24 \mathrm{hrs}$. dipstick 1+) in a previously normotensive patient.

As evidenced by many studies, pre-eclampsia is a disorder associated with generalised dysfunction of endothelial cells. This endothelial dysfunction is proposed to be a part of an exaggerated maternal inflammatory response to pregnancy. There are numerous markers like activated complement, cytokines, tumour necrosis factor $\alpha(\mathrm{TNF} \alpha)$, interleukins and C-reactive protein, etc. which have been identified to detect 
low-grade systemic inflammation. Among the various markers of inflammation, C-reactive protein is a strongly associated marker with inflammatory process and is a sensitive index of overall inflammatory activity in the body.

Among various markers of inflammation in preeclampsia, C-reactive protein is strongly associated with inflammatory process and is a sensitive index of overall inflammatory activity in the body (Kluft C, De Maat et al 2002). ${ }^{1}$

Many studies have hypothesised that hypertension may be the result of an inflammatory disorder. Higher levels of Creactive protein may increase blood pressure by reducing nitric oxide production in endothelial cells causing vasoconstriction and increasing endothelin-1 (Sesso HD, Burning JE, Rifai N, et al 2003). ${ }^{2}$

C-reactive protein, a sensitive marker of tissue damage and inflammation was proposed to play a role in eliciting the inflammatory response characteristic of preeclampsia. The present study is directed towards determining the association of serum C-reactive protein and preeclampsia.

Study on C-reactive protein in preeclampsia will serve as a standard guideline for this part of the country.

\section{MATERIALS AND METHODS}

The study has been conducted in the Dept. of Obstetrics and Gynaecology, Patna Medical College and Hospital, Patna. Serum estimation of C-reactive protein was done in Dept. of Biochemistry in diagnosed cases of pre-eclampsia.

The pregnant women for this study were divided into two groups.

Group- I 50 cases of healthy pregnant normotensive women were selected as control group in age group of $20-35$ yrs.

Group- II 150 cases in the age group of 20 - 35 were selected for study from antenatal clinic, labour room and indoor of Obst and Gynae Dept., Patna Medical College, Patna.

Only 50 cases were taken as control to cut the cost of biochemical investigation.

All the women were in the third trimester of pregnancy in both the study and control group.

\section{Exclusion Criteria}

Those patients who were taking drugs or suffering from chronic renal disease, liver diseases, diabetes mellitus, chronic hypertension, HIV infections were excluded from the study.

\section{Study Plan}

Both groups after taking their consent were subjected to a questionnaire. Thereafter sample of blood was taken for analysis and biochemical investigation was done.

Following details were collected from all the 200 study subjects ( 150 cases and 50 controls).

a. Detailed history was taken from patient.

b. General examination- Including blood pressure.

c. Obstetrical examination.

Quantitative estimation of serum C-reactive protein was done by turbidimetric method.

Study Design- Observational Study.

Statistical method for analysis of the result- Data were presented as mean \pm SD and range values. Comparison of control group and study group were done by chi-square test. For all the tests, the probability value (P-value) of less than 0.05 was considered statistically significant.

\section{RESULTS}

\begin{tabular}{|c|c|c|c|}
\hline Cases & Primigravida & Multigravida & Total \\
\hline Number & 88 & 62 & 150 \\
\hline Percentage & 58.67 & 41.33 & 100 \\
\hline
\end{tabular}

Table 1. Distribution of Cases in Primigravidae and Multigravidae

\begin{tabular}{|c|c|c|c|c|c|c|c|}
\hline \multirow{2}{*}{$\begin{array}{c}\text { Sl. } \\
\text { No. }\end{array}$} & Groups & \multicolumn{2}{|c|}{ Low S.E.S } & \multicolumn{2}{c|}{ Middle S.E.S } & \multicolumn{2}{c|}{ High S.E.S } \\
\cline { 2 - 7 } & $\begin{array}{c}\text { No. of } \\
\text { Cases }\end{array}$ & $\%$ & $\begin{array}{c}\text { No. of } \\
\text { Cases }\end{array}$ & $\begin{array}{c}\text { \%o. of } \\
\text { Cases }\end{array}$ & $\%$ \\
\hline 1. & Control Gr & 20 & 40 & 27 & 54 & 3 & 6 \\
\hline 2. & Study Gr & 90 & 60 & 59 & 39.33 & 1 & 0.006 \\
\hline
\end{tabular}

Table 2. Distribution of Cases in Different Socioeconomic Groups

\begin{tabular}{|c|c|c|c|c|c|c|c|c|}
\hline \multirow{2}{*}{$\begin{array}{c}\text { Sl. } \\
\text { No. }\end{array}$} & \multirow{2}{*}{$\begin{array}{c}\text { Group of } \\
\text { Cases }\end{array}$} & \multicolumn{3}{|c|}{$\begin{array}{c}\text { Systolic B.P. } \\
\text { (mmH) }\end{array}$} & \multicolumn{3}{c|}{$\begin{array}{c}\text { Diastolic B.P. } \\
\text { (mmHg) }\end{array}$} \\
\cline { 4 - 9 } & & Range & Mean & SD & Range & Mean & SD \\
\hline 1. & $\begin{array}{c}\text { Control } \\
\text { Gr }\end{array}$ & 50 & $100-130$ & 117.88 & 9.67 & $60-90$ & 74.44 & 7.81 \\
\hline 2. & $\begin{array}{c}\text { Study } \\
\text { Gr }\end{array}$ & 150 & $140-190$ & 163.37 & 16.63 & $90-120$ & 108.50 & 7.08 \\
\hline
\end{tabular}

\begin{tabular}{|c|c|c|c|c|c|c|c|c|c|}
\hline \multirow{2}{*}{ Sl. No. } & \multirow{2}{*}{ Group } & \multirow{2}{*}{$\begin{array}{l}\text { No. of } \\
\text { Cases }\end{array}$} & \multicolumn{4}{|c|}{ CRP Concentration (mg/L) } & \multirow{2}{*}{ ' $\mathrm{t}$ ' } & \multirow{2}{*}{ 'p' } & \multirow{2}{*}{ Remark } \\
\hline & & & Range & Mean & SD & Sem & & & \\
\hline 1. & Control Gr & 50 & $2.2-16.15$ & 9.64 & 3.79 & 0.53 & \multirow{2}{*}{35.29} & \multirow{2}{*}{$<0.001$} & \multirow{2}{*}{ Significant } \\
\hline 2. & Study Gr & 150 & $30.12-90.0$ & 55.03 & 14.31 & 1.16 & & & \\
\hline
\end{tabular}

Table 4. Table showing Range, Mean, SD, SEM ' $t$ ' and ' $p$ ' Value of C-Reactive Protein (CRP) Concentration in Different Groups

\begin{tabular}{|c|c|c|c|c|c|c|c|c|c|c|c|c|}
\hline \multirow{3}{*}{ Age in Yrs. } & \multicolumn{5}{|c|}{ Control Group } & \multirow{2}{*}{\multicolumn{5}{|c|}{$\begin{array}{c}\text { Study Group CRP Concentration mg/dL } \\
\text { CRP Concentration (mg/L) }\end{array}$}} & \multirow{3}{*}{ T and $P$ Value } & \multirow{3}{*}{$\mathbf{R}$} \\
\hline & \multicolumn{5}{|c|}{ CRP Concentration (mg/L) } & & & & & & & \\
\hline & No. & Mean & SD & SEM & Range & No. & Mean & SD & SEM & Range & & \\
\hline $20-25$ & 6 & 8.58 & 5.19 & 2.12 & 13.33 & 82 & 51.76 & 13.15 & 1.45 & 59.88 & $\begin{array}{l}t=16.78 \\
p=<0.001\end{array}$ & $\mathbf{s}$ \\
\hline $26-30$ & 30 & 9.23 & 3.68 & .67 & 13.9 & 60 & 59.33 & 14.56 & 1.88 & 55.88 & $\begin{array}{c}\mathrm{t}=25 \\
\mathrm{P}=<0.001\end{array}$ & $\mathbf{s}$ \\
\hline
\end{tabular}

(S- Significant) 


\section{DISCUSSION}

Pre-eclampsia is a multisystem disorder that complicates $3 \%$ - 8\% of pregnancies.

Study done on 150 patients of pre-eclampsia in which 88 cases $(58.67 \%)$ were primigravida, while 62 cases $(41.33 \%)$ were multigravida. This concludes that the majority of cases affected by pre-eclampsia were primigravida, which is similar with the finding of study conducted by Zenebe Woldie et al (2010). ${ }^{3}$

The incidence of pre-eclampsia ranges from $3 \%$ to $7 \%$ among primigravidae and $1 \%$ to $3 \%$ among multigravidas as documented by Uzan et al (2011).

In the present study, $60 \%$ cases of pre-eclampsia were from low socioeconomic status and $39.33 \%$ belonged to middle socioeconomic status, while only one case was of high socioeconomic status. Hence, according to this study majority of the patients affected by pre-eclampsia were of low socioeconomic group followed by middle socioeconomic group. This shows that there is statistically significant association of pre-eclampsia with socioeconomic group. This is similar to the finding of Zenebe Wolde et al [2010],3 whose study has shown that there is more prevalence of preeclampsia in patients of lower socioeconomic group.

Systolic blood pressure in control group ranged from 100 - $130 \mathrm{mmHg}$ with mean value of $117.88 \mathrm{mmHg}$ (SD 9.67). In study group, the systolic blood pressure ranged from 140 $190 \mathrm{mmHg}$ with mean value of $163.37 \mathrm{mmHg}$ (SD 16.63).

The diastolic blood pressure range for control group was 60 - $90 \mathrm{mmHg}$ with the mean value of $74.44 \mathrm{mmHg}$ (SD 7.81). Among study group diastolic blood pressure ranged between $90-120 \mathrm{mmHg}$ with the mean value of $108.50 \mathrm{mmHg}$ (SD 7.08).

These findings are consistent to the findings of Sibai B and Dekker G et al (2005). ${ }^{4}$ This is also similar to study conducted by Uzan et al (2011) on pre-eclampsia, where all of the cases were having diastolic blood pressure $\geq 140 / 90$ mmHg.

There are numerous markers like activated complement, cytokines, tumour necrosis factor (TNF $\alpha$ ), interleukins and C-reactive protein, etc. which have been identified to detect low-grade systemic inflammation.

In present study, serum C-reactive protein were estimated in 50 normotensive pregnant (Control group) women and 150 clinically proven patients of pre-eclampsia (Study group).

In the present study, C-reactive protein value in control ranged from $2.2 \mathrm{mg} / \mathrm{L}$ to $16.16 \mathrm{mg} / \mathrm{L}$ with a mean value of $9.64 \mathrm{mg} / \mathrm{L}$ (SD 3.79). In the Study group, C-reactive protein value ranged from 30.12 to $90 \mathrm{mg} / \mathrm{L}$ with a mean value of
$55.03 \mathrm{mg} / \mathrm{L}$ (SD 14.31). The ' $\mathrm{t}$ ' value was 35.29 and ' $\mathrm{p}$ ' value was $<0.001$, which is significant statistically.

The mean CRP level was significantly higher in patients of study group in all age groups as compared to control with ' $\mathrm{p}$ ' value $<0.001$.

Thus, serum C-reactive protein value was markedly raised in proven cases of pre-eclampsia than their control group, which is consistent with the findings of $\mathrm{E}$ Teran, $\mathrm{C}$ Escudro et al (2001), Tjoa MLvan Vugt et al (2003), Qiu C et al (2004), Delia M Paternoster et al (2006) ${ }^{5}$, Kumru et al (2006), I Batashki et al (2006), A Ghazavi et al (2008), Zacho J et al (2008), 6 Mihu D et al (2008)7 and Kazerooni et al (2009), A. Szarka et al (2010) and Nanda K et al (2012). ${ }^{8}$

\section{CONCLUSION}

Among various markers of inflammation in pre-eclampsia, Creactive protein is strongly associated with inflammatory process and is a sensitive index of overall inflammatory activity in the body as CRP is markedly elevated in cases of pre-eclampsia.

\section{REFERENCES}

[1] Kluft C, de Maat MP. Sensitive markers of inflammation make it possible to study the chronic process: the rise of interest in low levels of C-reactive protein. Vascul Pharmacology 2002;39(3):99-104.

[2] Sesso HD, Burning JE, Rifai N, et al. C-reactive protein and the risk of developing hypertension, JAMA 2003;290(22):2945-51.

[3] Wolde Z, Segni H, Woldie M. Hypertensive Disorders of pregnancy in Iimma University specialized hospital. Ethiop J Health Sci 2011;21(3):147-54.

[4] Sibai B, Dekker G, Kupferminc M. Pre-eclampsia. Lancet 2005;365(9461):785-99.

[5] Paternoster DM, Fantinato S, Stella A, et al. C-reactive protein in hypertensive disorders in pregnancy. Clin Appl Thrombo/Hemost 2006;12(3):330.

[6] Zacho J, Tybjaerg-Hansen A, Jensen JS, et al. Genetically elevated C-reactive protein and ischemic vascular disease. N Engl J Med 2008;359(18):1897908.

[7] Mihu D, Costin N, Mihu CM, et al. C-reactive protein, marker for evaluation of systemic inflammatory response in preeclampsia. Rev Med Chir Soc Med Nat Lasi 2008;112(4):1019-25.

[8] Nanda K, Sadanand G, Krishna MCS, et al. C-reactive protein as a predictive factor of preeclampsia. Int J Biol Med Res 2012;3(1):1307-10. 